\title{
QUANTITATIVE STUDIES OF THE VAGINAL FLORA OF HEALTHY WOMEN AND OF OBSTETRIC AND GYNAECOLOGICAL PATIENTS
}

\author{
J. G. E. M. LindneR*, F. H. F. Plantema † AND \\ JACOMINA A. A. HoOgKamp-KorstanjE* \\ *Laboratory of Microbiology, State University Utrecht, Catharijnesingel 59, Utrecht, and \\ $\dagger$ Department of Obstetrics and Gynaecology, Grootziekengasthuis, Nieuwstraat 34, \\ 's-Hertogenbosch, The Netherlands
}

INTEREST in the bacterial flora of the female genital tract is increasing because of its relation to obstetric and gynaecological infections. Most studies, however, were undertaken before modern anaerobic techniques came into use, and they were not quantitative.

Numerous investigations have shown that a wide range of micro-organisms including diphtheroids (Carter and Jones, 1937), mimae (de Bord, 1943), bifidobacteria (Montagna and Cataldi, 1944), gram-positive anaerobic cocci and veillonellae (Hite, Hesseltine and Goldstein, 1947), Haemophilus vaginalis (Leopold, 1953), leptotrichiae and anaerobic vibrios (Moore, 1954) and the Döderlein bacillus (Hunter, Long and Schumacher, 1959) belong to the normal vaginal flora. The differences between the results of the various investigations may be a reflection of differences in sampling techniques, in the time of sampling in relation to the menstrual cycle, in the sites of sampling and in cultural methods.

In more recent studies with adequate anaerobic techniques Gorbach et al. (1973) demonstrated the predominance of Lactobacillus and Bacteroides spp. in the cervical flora. Pearson and Anderson (1970), Swenson et al. (1973) and Thadepalli, Gorbach and Keith (1973) showed that anaerobes are often involved in infections of the female genital tract. It is likely that these organisms belong to the normal cervical and vaginal flora. Further study of this flora, preferably with quantitative methods, is required.

Longitudinal studies carried out by Goplerud, Ohm and Galask (1976) demonstrated a fairly constant cervical flora in women during pregnancy and the puerperium. The present communication describes a study in which the vaginal and cervical flora of a well-defined group of healthy women was cultured quantitatively. The normal adult flora was compared with that of women in pregnancy and of women with cervicitis.

\section{MATERIAL AND METHODS}

Subjects. Women included in this study were selected from the patients at the obstetric and gynaecological department of the Grootziekengasthuis, 's-Hertogenbosch, the Netherlands. The study was based on three groups of women. Group I consisted of 42 healthy

Received 24 Oct. 1977; accepted 7 Nov. 1977. 
adult women without any gynaecological disorder. Most of them visited the clinic for a routine examination after tubal coagulation. They all had a regular menstrual cycle, did not receive antibiotics or oral contraceptives and did not use intra-uterine devices. Fifty-three cervical and 50 high vaginal (fornical) specimens were collected. Group II consisted of 85 adult women in uncomplicated pregnancy; 118 cervical and 22 high vaginal specimens were collected. Group III consisted of 57 patients with cervicitis not caused by gonococci or Candida albicans; 57 cervical and 56 high vaginal specimens were collected.

Specimens. In group I, specimens were collected on any day of the menstrual cycle; in group II, from the 6th week to the end of pregnancy; in group III, at the first visit, before therapy was administered.

In all women an unlubricated speculum was used to observe the cervix. Fluid was obtained from the endocervix and from the posterior fornix by means of sterile calibrated " cervical slimesuckers" (Continental Pharma, Zutphen, Holland) with blunt ends.

After measuring the volume in the sucker (generally $0.01-0.3 \mathrm{ml}$ ) the specimen was mixed with $20 \mathrm{ml}$ of a prereduced transport medium (van der Wiel-Korstanje and Winkler, 1970). This mixture was used for quantitative and qualitative bacteriological culture. A second specimen, taken with a swab from the endocervix, was used to prepare a smear for the detection of Trichomonas vaginalis.

Cultural methods. All samples were cultured within $2 \mathrm{~h}$ of collection. After homogenisation, 10-fold dilutions were made from $10^{2}-10^{5}$ in transport medium. From appropriate dilutions, $0.03-\mathrm{ml}$ samples were plated in duplicate on the following six media: sheep blood (5\%) agar, for most aerobic bacteria; lysed horse blood $(5 \%)$ agar with $\mathrm{V}$ factor, for Haemophilus spp.; MacConkey's agar (Oxoid CM7b), for coliforms; enriched blood agar (RCA, Oxoid CM151) with $7.5 \%$ horse blood, for many anaerobes; the agar medium of de Man, Rogosa and Sharpe (1960) (MRS Oxoid CM361), for lactobacilli; a medium (HVL), for Gram-negative anaerobes, that consisted of the Viande-Levure medium of Beerens and Fievez (1971) supplemented with haemin (Fluka, A.G.), neomycin sulphate (Lundbeck) $100 \mathrm{mg}$ per litre, vancomycin $\mathrm{HCl}$ (Lilly) $7.5 \mathrm{mg}$ per litre according to Finegold, Sugihara and Sutter (1971) and 1.5\% agar (Bacto Difco).

All anaerobic media were used freshly poured or kept reduced in a nitrogen atmosphere. Aerobic plates were incubated for 2 days; anaerobic plates were incubated in jars with an atmosphere of $90 \% \mathrm{H}_{2}$ and $10 \% \mathrm{CO}_{2}$ for $3-5$ days at $37^{\circ} \mathrm{C}$.

Viable counts and statistical analysis. The numbers of different colony-forming units on the various selective and non-selective media were expressed as the $\log _{10}$ of the number of identified organisms per $\mathrm{ml}$ of cervical or high vaginal fluid. The sum of the colony counts gave the total viable count. Geometric means and standard deviations were calculated. The statistical significances of the differences in bacterial counts between groups of women were determined by the Student $t$-test.

Differences between groups of women in respect of the isolation rates of various bacterial species were tested for significance by the chi-square test at the $1 \%$ and $5 \%$ level $(P=0.01$ and 0.05 respectively).

Isolation. A Gram-stained film was made of each different type of colony obtained on solid medium and the colonies were tested for the production of catalase. Subcultures were made on blood agar for aerobic bacteria and on HVL medium, RCA blood agar and MRS agar for anaerobic bacteria. All strains isolated on anaerobic plates were tested for growth under both aerobic and anaerobic conditions.

Identification procedures. Aerobic bacteria were identified by standard biochemical and serological tests as detailed by Cowan and Steel (1974) and Blair, Lennette and Truant (1970).

Anaerobic bacteria were identified by the procedures outlined by Holdeman and Moore (1972). Gas chromatographic analysis of fatty acid end-products was performed according to Lindner and Marcelis (1978).

\section{RESULTS}

A total of 228 women fulfilled the criteria outlined for inclusion in this study. Specimens were obtained from the cervix and fornix of most women. To 
minimise the risk of iatrogenic infection in the pregnant group, usually only a cervical specimen was taken.

A total of 356 specimens were used for quantitative culture. In most instances the RCA, MRS and HVL plates incubated anaerobically yielded the highest viable counts $\left(10^{8}-10^{10}\right.$ bacteria per $\left.\mathrm{ml}\right)$ in fluid from the cervix or fornix.

Negative cultures $\left(<10^{4}\right.$ bacteria per ml) were obtained from $13 \%$ of 53 cervical specimens in group I, $4 \%$ of 118 in group II, and $8 \%$ of 57 in group III; the three groups respectively gave negative cultures from $10 \%$ of 50 fornical specimens, $5 \%$ of 22 and $6 \%$ of 56 (fig. 1).

In group I (healthy non-pregnant women), cultures from $42 \%$ of cervical and $32 \%$ of high vaginal specimens yielded only one bacterial species, but sometimes two, and occasionally more, were obtained from a specimen. The mean number of species was 1.5 from cervical and 1.9 from high vaginal specimens.

In group II (healthy pregnant women), only one species was obtained from $61 \%$ of cervical and $35 \%$ of high vaginal specimens. The difference between groups I and II in terms of the yield of pure cultures from cervical specimens was

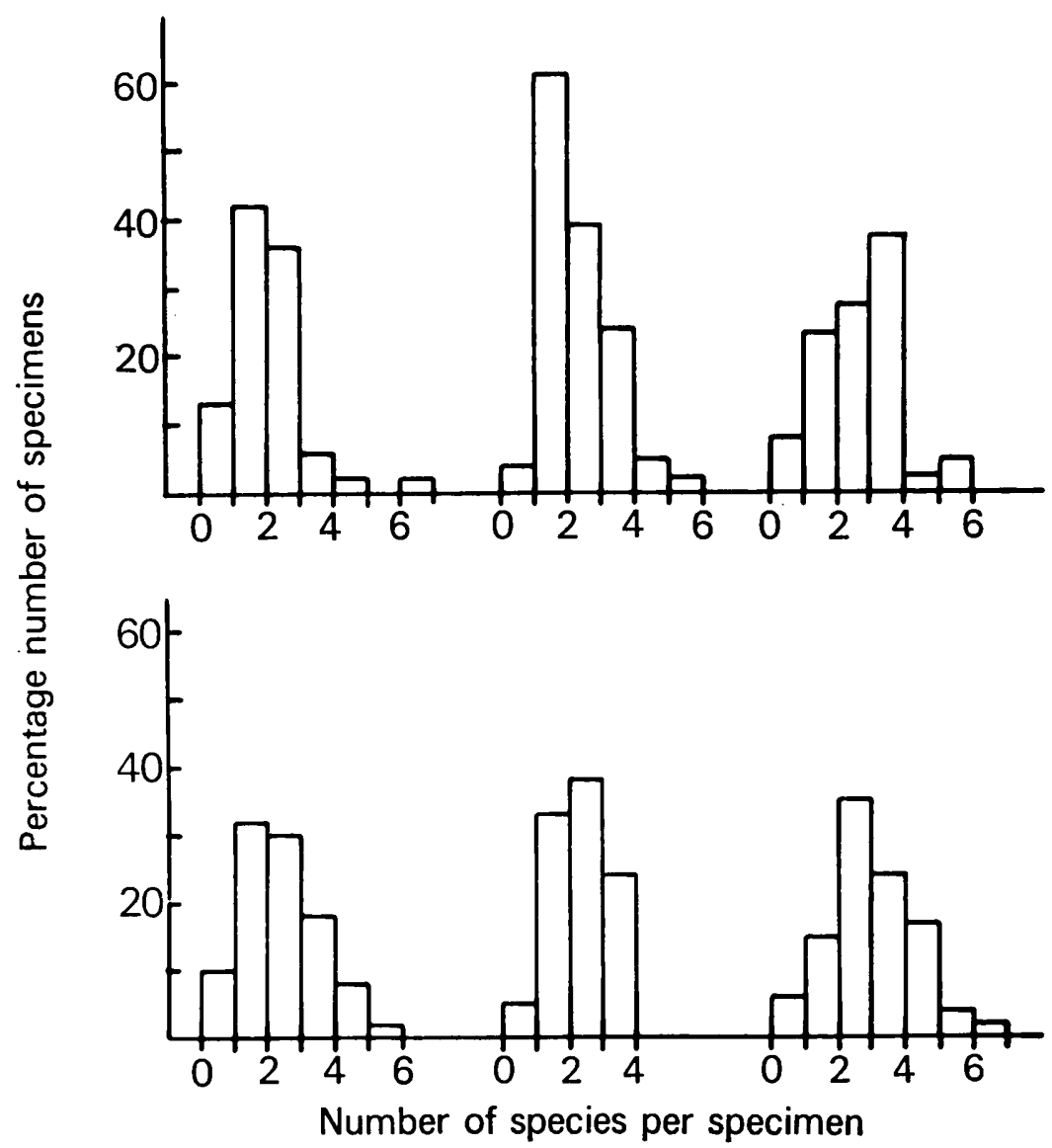

FIG. 1.-Percentage distribution of number of species per specimen. Upper row, cervical specimens; lower row, high vaginal specimens; left, group I; middle, group II; right, group III. 
statistically significant $(\mathrm{P}<0.01)$. Groups I and II were comparable in respect of the frequency with which specimens yielded two or more bacterial species; the means of the number of species obtained were 1.5 for cervical and 1.7 for high vaginal specimens.

In group III (women with cervicitis), $23 \%$ of the cervical and $15 \%$ of the high vaginal specimens yielded a single species. More frequently, two or more species were isolated, and occasionally as many as six. The means of the number of species were 2.2 for cervical and 2.5 for high vaginal specimens. The difference between the means of the number of species from cervical specimens of groups I and III is statistically significant $(P<0.01)$.

The organisms isolated and the viable counts obtained are given in the table. In all groups, specimens yielding only one species were derived more frequently from the cervix than from the fornix. Total viable counts ranged from $10^{8}-10^{10}$ bacteria per $\mathrm{ml}$.

TABLE

Isolation rates of microbial species and mean viable counts of organisms in samples from healthy non-pregnant adult women (group I), pregnant women (group II) and women with cervicitis (group $I I I)$

\begin{tabular}{|c|c|c|c|c|c|c|}
\hline \multirow{3}{*}{ Organism } & \multicolumn{6}{|c|}{$\begin{array}{l}\text { Mean } \log _{10} \text { number of viable organisms per ml, } \pm \mathrm{SD} \text {, and } \\
\text { isolation rate* (per cent.) in specimens from women of groups }\end{array}$} \\
\hline & \multicolumn{2}{|r|}{ I } & \multicolumn{2}{|c|}{ II } & \multicolumn{2}{|c|}{ III } \\
\hline & $\begin{array}{c}\text { Cervical } \\
\text { specimens } \\
(53)\end{array}$ & $\begin{array}{l}\text { Fornical } \\
\text { specimens } \\
\quad(50)\end{array}$ & $\begin{array}{l}\text { Cervical } \\
\text { specimens } \\
\text { (118) }\end{array}$ & $\begin{array}{l}\text { Fornical } \\
\text { specimens } \\
\text { (22) }\end{array}$ & $\begin{array}{l}\text { Cervical } \\
\text { specimens } \\
(57)\end{array}$ & $\begin{array}{l}\text { Fornical } \\
\text { specimens } \\
(56)\end{array}$ \\
\hline Staph. albus & $\begin{array}{c}8 \cdot 2 \pm 1 \cdot 9 \\
12\end{array}$ & $\begin{array}{c}8 \cdot 0 \pm 1 \cdot 5 \\
10\end{array}$ & $\begin{array}{c}7 \cdot 3 \pm 0 \cdot 7 \\
3\end{array}$ & $\begin{array}{c}8 \cdot 7 \\
5\end{array}$ & $\begin{array}{c}6 \cdot 6 \pm 2 \cdot 0 \\
12\end{array}$ & $\begin{array}{c}6.9 \pm 1 \cdot 2 \\
21\end{array}$ \\
\hline $\begin{array}{l}\text { Non-haemolytic and } \\
\alpha \text {-haemolytic streptococci }\end{array}$ & $\begin{array}{c}8 \cdot 0 \pm 1 \cdot 1 \\
20\end{array}$ & $\begin{array}{c}7 \cdot 7 \pm 1 \cdot 4 \\
10\end{array}$ & $\begin{array}{c}8 \cdot 0 \pm 1 \cdot 1 \\
8\end{array}$ & $\begin{array}{c}9 \cdot 3 \pm 1 \cdot 0 \\
9\end{array}$ & $\begin{array}{c}7 \cdot 4 \pm 1 \cdot 2 \\
27\end{array}$ & $\begin{array}{c}7 \cdot 7 \pm 1 \cdot 2 \\
28\end{array}$ \\
\hline$\beta$-Haemolytic streptococci & $\cdots$ & $\cdots$ & $\underset{3}{8 \cdot 8 \pm 1 \cdot 0}$ & $\cdots$ & $\frac{6 \cdot 2 \pm 0 \cdot 8}{4}$ & $\begin{array}{c}6 \cdot 3 \\
2\end{array}$ \\
\hline Enterobacteriaceae & $\frac{6 \cdot 4 \pm 0 \cdot 6}{6}$ & $\frac{6 \cdot 6 \pm 1 \cdot 0}{6}$ & $\begin{array}{c}7 \cdot 5 \pm 0 \cdot 6 \\
6\end{array}$ & $\begin{array}{c}5 \cdot 3 \\
5\end{array}$ & $\ldots$ & $4 \cdot 6 \pm 0 \cdot 4$ \\
\hline Diphtheroids & $\begin{array}{c}5 \cdot 3 \\
2\end{array}$ & $\frac{8 \cdot 1 \pm 1 \cdot 9}{8}$ & $8 \cdot 6 \pm 1 \cdot 8$ & $\cdots$ & $\begin{array}{c}6 \cdot 5 \pm 1 \cdot 9 \\
10\end{array}$ & $\frac{8 \cdot 6 \pm 1 \cdot 4}{4}$ \\
\hline Lactobacillus spp. & $\underset{72}{7 \cdot 4 \pm 1 \cdot 2}$ & $\begin{array}{c}8 \cdot 6 \pm 1 \cdot 2 \\
80\end{array}$ & $\begin{array}{c}8 \cdot 1 \pm 1 \cdot 0 \\
92\end{array}$ & $\begin{array}{c}7 \cdot 3 \pm 2 \cdot 3 \\
86\end{array}$ & $\begin{array}{c}7 \cdot 7 \pm 1 \cdot 2 \\
65\end{array}$ & $\begin{array}{c}8 \cdot 1 \pm 1 \cdot 2 \\
84\end{array}$ \\
\hline Peptostreptococcus spp. & $\underset{6}{8.4 \pm 0.4}$ & $\cdots$ & $\frac{6 \cdot 5 \pm 1 \cdot 7}{2}$ & ... & $\begin{array}{c}7 \cdot 6 \pm 1 \cdot 3 \\
20\end{array}$ & $\begin{array}{c}7 \cdot 6 \pm 0 \cdot 4 \\
21\end{array}$ \\
\hline Peptococcus spp. & $\begin{array}{c}7 \cdot 5 \pm 1 \cdot 6 \\
4\end{array}$ & $\frac{7 \cdot 8 \pm 1}{4}$ & $\cdots$ & $\ldots$ & $\ldots$ & $\cdots$ \\
\hline Bacteroides spp. & $\begin{array}{c}7 \cdot 8 \pm 0 \cdot 4 \\
4\end{array}$ & $\underset{4}{8 \cdot 3} \pm 1 \cdot 4$ & $\begin{array}{c}7 \cdot 2 \\
1\end{array}$ & $\begin{array}{c}7 \cdot 0 \\
5\end{array}$ & $\begin{array}{c}8 \cdot 2 \pm 1 \cdot 2 \\
27\end{array}$ & $\begin{array}{c}7 \cdot 8 \pm 1 \cdot 7 \\
28\end{array}$ \\
\hline Yeasts & $\begin{array}{c}6.4 \pm 0.9 \\
12\end{array}$ & $\begin{array}{c}7 \cdot 2 \pm 0 \cdot 7 \\
16\end{array}$ & $\begin{array}{c}6.0 \pm 0.6 \\
10\end{array}$ & $\begin{array}{c}6 \cdot 1 \pm 1 \cdot 1 \\
9\end{array}$ & $5 \cdot \frac{5}{7} 0 \cdot 7$ & $\frac{6 \cdot 2 \pm 1 \cdot 3}{9}$ \\
\hline
\end{tabular}

* Bold numerals. 
Lactobacilli predominated; the mean isolation rate from the three groups was almost $80 \%$, and the mean viable count in fluid was $10^{8}$ per $\mathrm{ml}$. In all three groups, the counts of various other organisms were comparable, reaching $10^{8}$ $10^{9} \mathrm{per} \mathrm{ml}$ for Staphylococcus albus, streptococci, and diphtheroids, and 107-108 for anaerobic cocci and bacteroides organisms. Yeasts were isolated in smaller numbers $\left(10^{6}-10^{7}\right.$ per $\left.\mathrm{ml}\right)$, and enterobacteria were even less numerous $\left(10^{6}\right.$ per $\mathrm{ml})$.

In group I, anaerobes such as peptostreptococci, peptococci and bacteroides were of low prevalence. Staph. albus, streptococci and yeasts (usually Candida albicans, but occasionally Torulopsis glabrata) were the most frequent aerobes. Enterobacteriaceae, mainly E. coli and Klebsiella and Enterobacter spp., occurred infrequently.

Lactobacilli occurred more frequently $(\mathrm{P}<0.01)$ in group II than in group I, but aerobic bacteria occurred less frequently. A $\beta$-haemolytic streptococcus of group B was isolated from one woman in group II.

In group III the isolation rates for peptostreptococci and Bacteroides spp. were significantly higher than in groups I and II $(\mathrm{P}<0.001)$; the same was true of Staph. albus and of streptococci $(\mathrm{P}<0 \cdot 05)$.

Bacteroides organisms belonged to the species $B$. fragilis subspecies fragilis, thetaiotaomicron, ovatus and vulgatus. In $81 \%$ of all cultures from group III, Trichomonas vaginalis could be demonstrated.

\section{Occurrence of lactobacilli}

As lactobacilli predominated, the frequency distribution of the counts of lactobacilli in the specimens from the three groups was determined (fig. 2). In healthy women, $28 \%$ of the cervical cultures and $20 \%$ of the high vaginal cultures were negative for lactobacilli $\left(<10^{4}\right.$ per $\left.\mathrm{ml}\right)$; in pregnant women the corresponding figures were $8 \%$ and $14 \%$, and in women with cervicitis $35 \%$ and $16 \%$. In the cultures positive for lactobacilli the counts per $\mathrm{ml} \mathrm{ranged} \mathrm{from} 10^{4}$ $10^{10}$. In group I, cervical specimens gave counts of $10^{7}-10^{8}$ per $\mathrm{ml}$, and high vaginal specimens counts of $10^{9}-10^{10} \mathrm{per} \mathrm{ml}$. In group II, most of the cervical specimens yielded $10^{8}-10^{9}$ lactobacilli per $\mathrm{ml}-10$ times more than from group I women - and the high vaginal specimens yielded $10^{7}-10^{8}$ per $\mathrm{ml}$, i.e., $10-20$ times less than from group I. In group III, counts of $10^{8}-10^{9}$ per ml were commonly obtained from specimens from both sampling sites.

\section{DisCussion}

Quantitative data on the endocervical flora of a large group of women have not been reported earlier as far as we know. The amount of fluid sampled was small and this raises the question of sampling error. In a number of instances two or three simultaneous samples from various sites in the fornix gave comparable results. Results obtained with consecutive cervical samples from the same women were reasonably consistent. It is of course not known whether the microbial flora in the fluid fully reflects the flora adhering to the vaginal wall (Mårdh and Weström, 1976). 

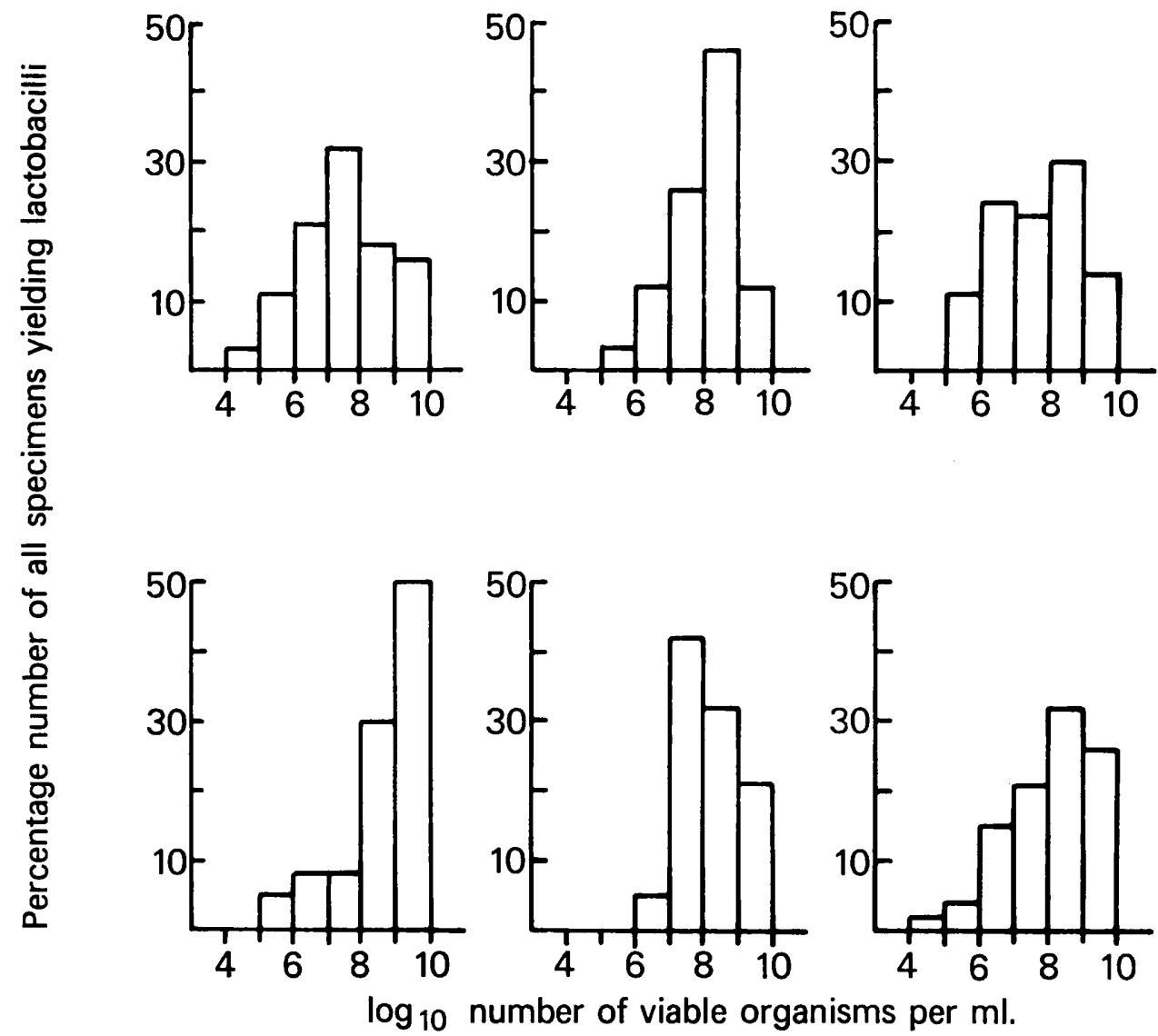

FIG. 2.-Frequency distribution of lactobacillus counts as a percentage of all specimens yielding lactobacilli. Upper row, cervical specimens; lower row, high vaginal specimens; left, group I; middle, group II; right, group III.

The dilution procedure required for quantitative analysis makes it possible that organisms present at less than $10^{4}$ per $\mathrm{ml}$ might have been missed. A disadvantage of the usual method of plating undiluted specimens on selective media is that transient contaminants from the skin or from the lower vagina might be regarded as belonging to the cervical flora. It is postulated that organisms present in small numbers, i.e., $<10^{6}$ per $\mathrm{ml}$ or $0.01 \%-0 \cdot 1 \%$ of the total count, cannot be considered indigenous unless they are regularly encountered.

Certain investigations in healthy women indicate that counts of $10^{9}-10^{10}$ bacteria per $\mathrm{ml}$ may be expected in vaginal specimens (de Boer, 1974; unpublished). Our data indicate that the cervical and high vaginal flora of healthy women with a normal menstrual cycle tends to be constant. The total viable counts averaged $10^{8}-10^{10}$ per $\mathrm{ml}$ in cervical or high vaginal fluid, though $13 \%$ of cultures were negative, i.e., the specimens contained $<10^{4}$ bacteria per $\mathrm{ml}$. Many different types of organism were isolated, but the yield from individual 
specimens was generally limited to one or two bacterial species. Lactobacilli predominated in the cervix as well as in the fornix. If no lactobacilli were present, organisms of one or two other species occurred in large numbers $\left(10^{8}-10^{10}\right.$ per $\left.\mathrm{ml}\right)$. Staph. albus and streptococci occurred in $10 \%-20 \%$ of the specimens; anaerobes occurred less commonly, but in similar numbers, and members of the Enterobacteriaceae were also less common and always occurred at lower counts $\left(10^{5}-10^{7}\right.$ per $\left.\mathrm{ml}\right)$. Streptococcus faecalis, regarded by some authors as a common member of the resident flora, was not found.

In pregnant women the total viable counts were comparable with those of non-pregnant healthy women and the flora seemed to be even more homogeneous, pure cultures being regularly obtained. Lactobacilli predominated in the flora.

In women with cervicitis the total viable counts were closely comparable with those of the other groups, but the flora was more heterogeneous and usually consisted of two or more bacterial species per specimen. There was a noticeably increased isolation rate of streptococci, peptostreptococci and Bacteroides spp. The majority of the Bacteroides spp. were $B$. fragilis subspecies fragilis, thetaiotaomicron, ovatus or vulgatus. These subspecies (now likely to be accorded separate species rank) are the most common causes of puerperal, post-abortion and pelvic infections (Parker and Jones, 1966; Sweet and Ledger, 1973). The role of anaerobic bacteria in cervicitis, however, is unknown and will not be elucidated until cervical specimens are cultured anaerobically as a routine. The increased prevalence of Bacteroides spp. and peptostreptococci indicates a disturbance of the normal flora, but it should be noted that infection with Trichomonas vaginalis was detected in $81 \%$ of our cervicitis cases.

\section{SUMMARY}

The cervical and high vaginal flora were studied by quantitative culture methods applied to 356 specimens from 53 healthy non-pregnant women, 102 pregnant women and 57 women with cervicitis. Specimens were obtained with a specially designed " slimesucker". In all groups the total viable counts ranged from $10^{8}-10^{10}$ bacteria per $\mathrm{ml}$ of fluid from the cervix and posterior fornix. There was only a slight difference between the flora of cervix and fornix.

In healthy women the means of the number of bacterial species per cervical and high vaginal specimen were 1.5 and 1.9 respectively. Lactobacilli predominated in $72 \%$ and $80 \%$ of cervical and high vaginal cultures respectively. Staphylococcus albus, non-haemolytic and $\alpha$-haemolytic streptococci, diphtheroids, peptostreptococci, peptococci and Bacteroides spp. could be isolated in high numbers, but less commonly than lactobacilli. Members of the Enterobacteriaceae and yeasts also occurred less commonly than lactobacilli, and in lower numbers $\left(10^{5}-10^{8}\right.$ organisms per $\left.\mathrm{ml}\right)$. It is postulated that the Enterobacteriaceae and yeasts are not part of the normal flora. In specimens from pregnant women the viable bacterial counts were comparable with those in specimens from healthy non-pregnant women. The flora was even more homogeneous during pregnancy, the means of the number of species being 1.5 
and 1.7 in cervical and high vaginal cultures respectively; lactobacilli occurred in $92 \%$ of the cervical and $86 \%$ of the high vaginal samples. In women with cervicitis the means of the number of species obtained from the cervix and fornix were $2 \cdot 2$ and $2 \cdot 5$, with lactobacilli predominating in $65 \%$ and $84 \%$ respectively. Bacteroides spp. and peptostreptococci were more commonly encountered in women with cervicitis than in those without, but the viable counts of these organisms were similar in all women. The role of bacteria in the production of cervicitis is discussed.

We are indebted to Coby van der Zon, Hanneke den Daas-Slagt, Cynthia RoemerDuttenhofer and Machiel de Vos for technical assistance and to J. H. Marcelis and Prof. Dr K. C. Winkler for statistical analysis and helpful advice.

This research was supported by a grant from Hoffmann-La Roche, Basel, Switzerland.

\section{REFERENCES}

BeERens, H. AND Fievez, L. 1971. Isolation of Bacteroides fragilis and SphaerophorusFusiformis groups. In Isolation of anaerobes, Society for Applied Bacteriology, Technical Series no. 5, edited by D. A. Shapton and R. G. Board, London, p. 109.

Blair, J. E., Lennette, E. H. AND TRUant, J. P. 1970. Manual of clinical microbiology, Baltimore.

BORD, DE, G. G. 1943. Species of the tribes Mimeae, Neisserieae and Streptococcaceae which confuse the diagnosis of gonorrhoea by smears. J. Lab. clin. Med., 28, 710.

CARTER, B. AND Jones, C. P. 1937. A study of the vaginal flora in the normal female. Sth. med. J., Bghm, Ala., 30, 298.

CowAN, S. T. AND STEEL, K. J. 1974. Manual for the identification of medical bacteria. 2nd ed., London.

Finegold, S. M., Sugihara, P. T. AND Sutter, V. L. 1971. Use of selective media for isolation of anaerobes from humans. In Isolation of anaerobes, Society for Applied Bacteriology, Technical Series no. 5, edited by D. A. Shapton and R. G. Board, London, p. 99.

Goplerud, C. P., OHM, M. J. AND Galask, R. P. 1976. Aerobic and anaerobic flora of cervix during pregnancy and puerperium. Am.J. Obstet. Gynec., 126, 858.

Gorbach, S. L., Menda, K. B., ThadePalli, H. and KeITH, L. 1973. Anaerobic microflora of the cervix in healthy women. Am.J. Obstet. Gynec., 117, 1053.

Hite, K. E., Hesseltine, H. C. AND Goldstein, L. 1947. A study of the bacterial flora of the normal and pathologic vagina and uterus. Am.J. Obstet. Gynec., 53, 233.

Holdeman, L. V. AND Moore, W. E. C. 1972. Anaerobe Laboratory Manual, 2nd ed., Virginia Polytechnic Institute and State University, Blacksburg.

Hunter, C. A., Long, K. R. AND Schumacher, R. R. 1959. A study of Döderlein's vaginal bacillus. Ann. N.Y. Acad. Sci., 83, 217.

LEOPOLD, S. 1953. Heretofore undescribed organisms isolated from a genito-urinary system. U.S. arm. Forces med. J., 4, 263.

LINDNER, J. G. E. M. AND MARCELIS, J. H. 1978. Quantitative gaschromatography of Bacteroides species under different growth conditions. Antonie van Leeuwenhoek, 44, 1.

Man, de, J. C., Rogosa, M. AND Sharpe, M. E. 1960. A medium for the cultivation of lactobacilli. J. appl. Bact., 23, 130.

MÅRDH, P. A. AND WESTRÖM, L. 1976. Adherence of bacteria to vaginal epithelial cells. Infect. Immun., 13, 661.

Montagna, C. P. AND Catald, M. S. 1944. Sobre la presencia de Lactobacillus bifidus en el meconio y en el ambiente vaginal de la madre. Revta Asoc. argent. Diet., $2,47$.

MOORE, B. 1954. Observations on a group of anaerobic vaginal vibrios. J. Path. Bact., 67, 461. 
Parker, R. T. And Jones, C. P. 1966. Anaerobic pelvic infection and developments in hyperbaric oxygen therapy. Am. J. Obstet. Gynec., 96, 645.

Pearson, H. E. AND Anderson, G. V. 1970. Bacteroides infections and pregnancy. Obstet. Gynec., N.Y., 35, 31.

Sweet, R. L. AND Ledger, W. J. 1973. Puerperal infectious morbidity. Am. J. Obstet. Gynec., 117, 1093.

Swenson, R. M., Michaelson, T. C., Daly, M. J. and Spaulding, E. H. 1973. Anaerobic bacterial infections of the female genital tract. Obstet. Gynec., N.Y., 42, 538.

Thadepalli, H., Gorbach, S. L. AND KeIth, L. 1973. Anaerobic infections of the female genital tract. Bacteriologic and therapeutic aspects. Am.J. Obstet. Gynec., 117, 1034.

Wiel-Korstanje, van DeR, J. A. A. AND WinkLeR, K. C. 1970. Medium for differential count of the anaerobic flora in human feces. Appl. Microbiol., 20, 168. 